\title{
Diógenes e o corpo "fabricador de drogas": o estatuto do corpo no uso abusivo de crack e nas situações de precariedade e vulnerabilidade social*1 $^{* 1}$
}

lara Flor Richwin*2 Luiz Augusto M. Celes*3

\begin{abstract}
Este artigo aborda a relação entre os modos de subjetivação resultantes das situações de vulnerabilidade social e o uso abusivo de crack. A partir de um estudo de caso clínico, examinou-se como a ação do crack sobre o corpo pulsional se liga à experiência do sujeito e à sua inscrição no laço social e na realidade sociocultural. Observou-se estreita articulação entre o estatuto do corpo engendrado pelo uso de crack e o lugar conferido ao corpo nas situações de precariedade e exclusão.
\end{abstract}

Palavras-chave: Crack, corpo, vulnerabilidade social, psicanálise

${ }^{* 1}$ Este artigo foi desenvolvido no âmbito da pesquisa de doutorado de Iara Flor Richwin Ferreira, ainda em andamento, sob orientação do Prof. Dr. Luiz Celes, no Programa de Pós-Graduação em Psicologia Clínica e Cultura/PCL/IP/UnB, em cotutela com a UFR Études Psychanalytiques/Université Paris-Diderot.

*22 Doutoranda na Universidade de Brasília - UnB (Brasília, DF, Br).

${ }^{* 3}$ Universidade de Brasília - UnB (Brasília, DF, Br). 
O fenômeno do crack tem ganhado, nos últimos anos, grande centralidade e destaque na cena social brasileira, emergindo como um dos mais visíveis sintomas sociais do "mal-estar na cultura". Os discursos midiáticos e as narrativas dominantes, por meio de um léxico alarmista, moral, trágico e bélico, propagam a ideia de uma epidemia incontrolável e enfatizam o crack como o responsável absoluto por inúmeras tragédias individuais, familiares e sociais, por trajetórias de degradação e fracasso e por perdas materiais, afetivas e morais (Lancetti, 2015; Rui, 2014). Contudo, a gravidade dessa situação não reside apenas na considerável competência desorganizadora e prejudicial do crack, mas se articula de maneira significativa com a alta vulnerabilidade social da maioria dos usuários (Bertoni \& Bastos, 2014).

Segundo Bertoni e Bastos (2014), dos 370.000 usuários regulares de crack no Brasil, cerca de $80 \%$ são pretos ou pardos; menos de $20 \%$ cursaram o ensino médio; $40 \%$ estão em situação de rua; cerca de $80 \%$ têm renda proveniente de empregos esporádicos e precarizados ou de esmolas, e quase $50 \%$ já foram presos pelo menos uma vez. Como apontam os dados, são histórias de vida marcadas pela precariedade, exclusão, racismo, baixa escolaridade, desemprego ou subempregos, vivência de rua e encarceramento. Essas características - em especial o fato de serem majoritariamente não brancos e a baixa escolaridade - constituem marcadores de uma desvantagem social presente já no início da vida e revelam origens familiares e inserções sociais de alta vulnerabilidade. A maioria dos usuários de crack, marcada pelo racismo e exclusão, entra na disputa por trabalho e posição social em franca desvantagem e fica exposta a diferentes formas de estigmatização, marginalização e às 


\section{ARTIGOS}

situações de violência e violação de direitos que lhe são intrínsecas. É patente, portanto, que a maioria dos usuários de crack é originária de uma classe social não apenas destituída de capital econômico e cultural, mas destituída, como apontado por Souza (2009), das próprias condições sociais, culturais e morais que permitiriam essa apropriação. Uma classe "condenada a ser 'corpo' sem alma ou mente" (p. 122).

Há, portanto, uma intrincada e complexa articulação entre vulnerabilidade social e uso abusivo e problemático de crack: tanto o uso de crack é um sintoma eloquente de dinâmicas sociais profundas de racismo, precariedade e exclusão social, quanto o uso compulsivo pode precarizar e vulnerabilizar ainda mais as condições sociais. A clínica com usuários de crack nos serviços da rede pública de saúde mental exige, incontornavelmente, um olhar e posicionamento clínicos que levem em consideração essa articulação.

Com o intuito de compreender a relação entre as incidências psíquicas e as lógicas de subjetivação resultantes das situações de precariedade e vulnerabilidade social e o destino psíquico e cultural em que o crack ganha uma centralidade problemática na vida dos sujeitos, apresentamos um estudo de caso acompanhado por uma das pesquisadoras ao longo de três anos em um Centro de Atenção Psicossocial Álcool e outras Drogas (CAPS-AD) de uma capital brasileira. ${ }^{1}$ A partir do referencial teórico-metodológico psicanalítico, pretende-se examinar como a ação do crack sobre o corpo e seus múltiplos efeitos sobre as sensações e dinâmicas pulsionais se ligam à experiência do sujeito, à sua relação com a alteridade, com o laço social e com a realidade sociocultural. A partir disso, pretende-se analisar e tecer articulações entre o estatuto do corpo que é engendrado pela operação de intoxicação pelo crack e o lugar que é conferido ao corpo pelo processo de produção da desigualdade social e marginalização na sociedade brasileira.

\section{Diógenes e o seu corpo fabricador de drogas}

Diógenes $^{2}$ foi encaminhado ao CAPS-AD em 2012 por uma comunidade terapêutica (CT) na qual estava internado. À época, tinha 37 anos, estava em

\footnotetext{
${ }^{1}$ A pesquisa clínica foi aprovada pelo Comitê de Ética em Pesquisa do Instituto de Ciências Humanas da UnB (CAAE: 61270116.4.0000.5540).

${ }^{2}$ Nome fictício, usado para proteger a privacidade e o anonimato do sujeito.
} 
processo de separação conjugal e tinha quatro filhos. Interrompeu os estudos na $3^{\text {a }}$ série do ensino fundamental e trabalhava como "camelô". ${ }^{3}$ Relatou que começou a usar maconha, merla, cola, loló e tabaco aos 13 anos; aos 18 começou a usar cocaína e bebida alcóolica e, aos 33, começou a usar crack. Desde então, usava crack, álcool e tabaco diariamente.

Nos quatro anos anteriores à internação na $\mathrm{CT}$, Diógenes consumia cotidianamente grandes quantidades de crack e de álcool, de forma abusiva e destrutiva, chegando a apresentar crises convulsivas e desmaios. Seus vínculos familiares e sociais estavam fragilizados ou rompidos e passava a maior parte do tempo nas ruas. Seu corpo estava emagrecido e marcado pelo uso abusivo da droga e pela vivência na rua. Sua linguagem empobrecida denunciava a defasagem do processo de escolarização e aquisição da linguagem.

Diógenes exprimia um sofrimento muito intenso, que tangenciava a insuportabilidade de existir e habitar seu corpo. Uma existência absorvida pela vontade feroz de usar a droga, e pela vontade, também feroz, de interromper o uso e alcançar a almejada abstinência. Relatava uma história marcada pela precariedade e pela marginalização, por violências sofridas e cometidas. Uma 468 vida sentida e narrada pelo próprio Diógenes por meio do fracasso e impotência, da degradação psíquica, corporal e moral, da "doença" da "perda da dignidade e do caráter".

Já nos seus primeiros contatos com o serviço, nos "avisou" que não gostava de falar de si e, principalmente, que não gostava de se envolver com os outros e compartilhar em grupo sua história de vida. Descrevia-se como arrogante, gostava "de aparecer" e dizia não tolerar ser contrariado ou frustrado, não aceitar receber ordens e se submeter a regras e ter dificuldades no convívio e relacionamento com os outros. "Não aguento ninguém perto de mim e se vier falar comigo eu me irrito".

Diógenes enfatizava sua vontade acentuada de usar o crack, uma "fissura" tão intensa que ele não conseguia ativar seu corpo por meio de exercícios físicos: "eu não tô conseguindo nem malhar na comunidade [terapêutica]. Meu coração acelera, me dá uma vontade ainda maior de fumar crack e eu fico nervoso e irritado". As falas de Diógenes centravam-se principalmente nos seus sintomas de abstinência, na intensa vontade que sentia de usar

\footnotetext{
${ }^{3}$ Para identificar as falas e expressões próprias do paciente, elas serão grafadas entre aspas e em itálico.
}

Rev. Latinoam. Psicopat. Fund., São Paulo, 20 (3), 465-480, set. 2017 


\section{ARTIGOS}

o crack e nas "perdas" que ele associava à sua trajetória de uso. Os conflitos nos relacionamentos interpessoais e no seu casamento eram atribuídos unicamente aos outros ou ao crack, que, segundo ele, havia destruído tudo e o transformado em um "monstro". Suas dificuldades no laço com o outro se manifestavam também na coletividade do CAPS, quando ficava muito irritado, impaciente e frustrado com intervenções de outras pessoas com as quais discordava.

Destacava-se no caso de Diógenes o predomínio de uma circulação repetitiva entre intoxicação, abstinência e recaídas. Sua existência via-se reduzida a esses ritmos, seu corpo regulado pelo uso e pela urgência da fissura e seus territórios geográficos e existenciais resumiam-se a um ciclo repetitivo entre zonas de uso/vivência de rua, cadeia e CT. Diógenes encontrava-se preso numa polaridade extremada entre abstinência absoluta e uso intenso - tudo ou nada - e a cada "recaída" essa palavra impunha com mais força o seu sentido de fracasso e impotência, levando a retomadas do uso muito mais graves, destrutivas e suicidárias.

Com efeito, após uma de suas recaídas mais graves, Diógenes cometeu duas tentativas de suicídio. A primeira, por ingestão de medicações psicotrópicas e, a segunda, após ter usado grande quantidade de crack, por ingestão de veneno para ratos ("chumbinho"), o que o levou a um estado grave de saúde e internação hospitalar. Depois de sair do hospital, procurou o CAPS e formulou a seguinte fala em uma reunião do grupo de psicoterapia: "Tudo em mim vira droga ... Tudo que eu tomo vira droga dentro do meu corpo. Me dá vontade de mais, mais, mais... se eu tomo uma dipirona, por exemplo, eu fico querendo mais dipirona, fico querendo sentir o gosto da dipirona na minha boca. Igual quando eu sai do hospital, tudo o que eu queria era sentir o gosto do chumbinho na minha boca".

A escolha de fazer desse paciente um caso de pesquisa decorre das inquietações, interrogações e desafios que ele suscita, solicitando um trabalho de reflexão clínica, ética e política. Se a narrativa de Diógenes traz à tona a força, os riscos e a potencialidade desorganizadora do crack, ela também revela que sua vinculação com a droga, bem como sua forma singular de vivenciá-la e significá-la, estão profundamente relacionadas com seu contexto sociocultural e marcadas pela trama das práticas e discursos dominantes construídos em torno do crack. Há, certamente, uma considerável competência prejudicial intrínseca ao crack, mas ela age sobre um terreno subjetivo e coletivo cuja estrutura e conjuntura devem ser examinadas. 


\section{Corpo e sensorialidade: dinâmicas pulsionais}

O registro do corpo é o domínio mais eminente no qual se expressa o mal-estar de Diógenes. Suas falas revelam que, tal como proposto por Costa (2005), seu corpo é colocado como objeto privilegiado de sua atenção, preocupações e sofrimentos conscientes, sendo explicitamente identificado como um dos principais componentes de seu conflito psíquico.

Percebe-se que o abuso da exploração das sensações corporais por meio do crack e outras drogas instaurou uma nova relação com seu corpo, promovendo significativas alterações na sua economia pulsional, na sua condição erógena e na sua relação com a linguagem, com o outro e com o mundo externo. Desde a adolescência, seu corpo foi constituído na interação com substâncias químicas que afetaram os circuitos de excitação, prazer e dor, alteraram suas "condições de sensibilidade" (Freud, 1930/2010a) e deixaram suas marcas nos arranjos e dinâmicas pulsionais na imbricação corpo-psiquismo.

Sua narrativa, focada na ambiguidade sensorial de prazer e dor provocada pelo crack, nas lembranças de satisfação, nos "sintomas de abstinência" e na vontade intensa que sentia de voltar a usar, colocam em cena, de forma onipresente, um corpo regulado predominantemente pelo uso e pela fissura. Um corpo que não suporta sequer sua estimulação por exercícios físicos, pois seus efeitos nos ritmos cardíacos trazem à memória corporal os efeitos do crack e atiçam uma urgência sentida como "física" em relação à substância, intensificando a falta da droga. Sua fala sobre o insuportável do exercício físico revela uma intolerância ao estado de excitação, ao aumento das tensões somáticas, sem que elas sejam descarregadas através do crack. A intoxicação tornou-se a via exclusiva de extinção da excitação. Quando Diógenes tenta não recorrer a essa via, qualquer estimulação de seu corpo torna-se insuportável.

A urgência física apresentada por Diógenes e a intolerância psíquica ao aumento da excitação corporal evidenciam uma tentativa de conceber o corpo como um simples epifenômeno de um jogo bio-químico-neuronal (Nogueira Filho, 1999), um corpo vivenciado como pura sensação, desancorado da palavra, do simbólico e do social. Faz-se um elogio do organismo em detrimento do corpo. Tal como o hipocondríaco, que tem sua alma confinada "no buraco de seu molar" (Freud, 1914/2010b, p. 26), Diógenes apresenta, inicialmente, sua existência absorvida pela urgência corporal, pelo estado de fissura, por uma espécie de dano corporal que a falta do crack lhe provoca. 


\begin{abstract}
ARTIGOS
O modelo pulsional do narcisismo mostra-se pertinente para a compreensão metapsicológica da questão do corpo no uso de crack: o retorno da libido retirada do mundo externo e dos investimentos objetais sobre o eu, que é, antes de mais nada, fundamentalmente derivado das sensações corporais (Freud, 1923/2006). Esse investimento narcísico em ação no uso de crack relaciona-se com uma tentativa de reconstituir e refazer o corpo, forjar um corpo novo, um corpo outro, orgânico e quimicamente regulado, que, a partir de um curto-circuito pulsional, busca situar-se às margens da linguagem, do laço social e do conflito psíquico, das dependências mais radicais e dos limites. ${ }^{4}$ Através do recurso ao crack, observamos uma tentativa de silenciar e dessubjetivar o corpo, subtraindo-o de sua dimensão simbólica e cultural. Como destacado por Assoun (2015), a centralidade e preponderância que o corpo ganha na dinâmica de uso de crack apontam para um retraimento do sujeito da fala e da linguagem. Diógenes nos "avisou" claramente: não quer falar, não gosta de falar de si.
\end{abstract}

\title{
Apetência insaciável: "Tudo que eu tomo vira droga dentro do meu corpo. Me dá vontade de mais, mais, mais...”
}

A fala de Diógenes, enunciada após a tentativa de suicídio, torna patente a dimensão de apetência e insaciabilidade, que o termo alemão usado por Freud para referir-se à toxicomania acentua - SüchtigKeit. A palavra sücht designa a apetência, uma necessidade que busca satisfazer-se intensamente, voltando a buscar incessantemente o objeto suscetível de satisfazer essa necessidade e crescendo em potência de tal maneira que adquire uma dimensão invasiva e patológica (Assoun, 2015).

Ao sair do hospital e ter uma vontade intensa de voltar a sentir o gosto do "chumbinho" em sua boca, Diógenes não a identifica com uma vontade de tentar novamente o suicídio. Associando-a com a mesma vontade que sente de repetir de forma incessante o uso de dipirona, de álcool ou de crack, Diógenes desloca a problemática dos "poderes destrutivos e diabólicos" e do "potencial aditivo" da droga e apreende no seu próprio "corpo fabricador de drogas", na

\footnotetext{
${ }^{4}$ Essa formulação teórico-clínica dialoga e vai de acordo com muitos dos autores que se dedicaram a uma compreensão psicanalítica da toxicomania (Assoun, 2015; Bucher, 1992; Gurfinkel, 2011; Le Poulichet, 1987; Nogueira Filho, 1999; Santiago, 2001).
} 


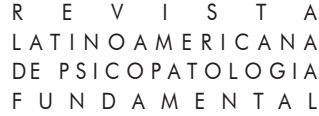

sua própria dinâmica pulsional, essa dimensão de apetência patológica. Não importa a substância que ele introduza - droga, veneno ou remédio - ela é transformada em seu corpo e produz-se uma excitação que se fixa como apetência devoradora e insaciável, que pede mais, mais, mais.

Essa apetência remete às figuras platônicas para representar o desejo humano: a tarambola, ave de corpo-tubo, pelo qual o alimento passa sem parar, que come e defeca permanentemente; o homem que versa azeite na jarra rachada sem nunca conseguir enchê-la. Essas imagens metaforizam a estrutura do desejo para Platão: sem limite, impossível de conter, insaciável, despótico, ávido e tirânico (Sissa, 1999). Nas falas de Diógenes, ecoa essa teoria platônica sobre o desejo, um querer mais que se agiganta em sua vida e que remete à ideia de um corpo esburacado e abissal, fissurado, incapaz de reter.

\section{Função do corpo e da exploração das sensações corporais no uso de crack}

Segundo a formulação freudiana, podemos compreender que Diógenes buscava influenciar seu organismo e modificar as suas "condições de sensibilidade" (Freud, 1930/2010a), redesenhando, em certa medida, os contornos do corpo próprio e colocando à prova seus limites. Diante dessa constatação clínica impõe-se um questionamento sobre a função da primazia do investimento sobre o corpo próprio e do recurso ao sensorial na vida de Diógenes. Mais precisamente, cabe interrogar como a ação do crack sobre o corpo e seus efeitos sobre as sensações e dinâmicas pulsionais se ligam à história e experiência de Diógenes, à sua relação com o outro, à sua inscrição na coletividade e no contexto sociocultural.

Em primeiro lugar, seguindo ainda a tese freudiana sobre as drogas presente em "O mal-estar na civilização", podemos compreender que a autoexploração e a estimulação abusiva de seu corpo, por meio da modificação das sensações, adquirem uma função de dessensibilização ao sofrimento e à dor. Segundo Freud (1930/2010a), os métodos mais interessantes para a prevenção do sofrimento são aqueles que buscam influenciar o próprio organismo. E o método químico é a maneira mais eficaz para exercer tal influência, provocar sensações de prazer imediatas, mas também modificar as próprias condições de nossa sensibilidade, de tal forma que nos torna inaptos à recepção de impulsos desprazerosos (Freud, 1930/2010a). Ainda que Diógenes não saiba nomeá-la, uma vez que sua dimensão subjetiva se encontra capturada pela falta da droga ou pelos pesados prejuízos secundários, cabe supor uma 


\section{ARTIGOS}

dor psíquica radical para a qual o crack e as outras drogas - operando por meio da supressão tóxica - constituem um remédio, um pharmakon, e não simplesmente a causa.

Em segundo lugar, remeto à formulação freudiana segundo a qual o método de intoxicação química produz também o ganho de um elemento de independência intensamente desejado em relação ao mundo externo. A vinculação com as drogas vai desengajar o sujeito parcialmente do mundo que lhe é tóxico e nocivo, permitindo-lhe "encontrar refúgio num mundo próprio, com melhores condições de sensibilidade" (Freud, 1930/2010a, p. 33). Retomando uma expressão de Cocteau (1985) quando passava por uma desintoxicação, podemos pensar que a droga "dá corpo" a Diógenes, um corpo com novas condições de sensibilidade, sustentado e protegido por um "costume de escafandrista" que, ao isolá-lo, possibilita que ele mantenha contato com o exterior e continue habitando o mundo, que para ele é tóxico e nocivo. Como destacado por Assoun (2015), se o drogado se intoxica, é porque ele ressente o cotidiano dos "não dependentes" como tóxico e, levando ao extremo o paradoxo que corresponde à sua posição subjetiva, porque ele tenta se desintoxicar. Parte-se do pressuposto de que a vida o "envenena" o bastante para que ele se "envenene" a si mesmo, por conta própria, preferindo um antídoto, por mais desastroso que ele seja, a seu incurável mal-estar.

\section{A toxicidade da instância do outro}

Para compreender a dimensão do isolamento de Diógenes e de sua relação quase exclusiva com o crack e o álcool faz-se necessário apreendê-la como uma versão da relação inconsciente a certa instância do outro. As graves dificuldades de Diógenes com relação à conviviabilidade e aos laços afetivos e sociais apontam para a suposição de certa toxicidade dos outros de sua história e do Outro de referência (Assoun, 2015).

O recurso ao investimento massivo e central na intoxicação pelo crack emerge, então, como uma tentativa de desembaraçar-se desses outros e buscar uma independência radical. Uma relação com o outro que não é sentida como segura e confiável leva Diógenes a tentar existir unicamente pela via da sensorialidade e do hiperinvestimento do corpo. Nesse sentido, a apetência insaciável discutida anteriormente, que toma a forma de uma necessidade física, exacerbada e tirânica da droga, pode ser compreendida como uma forma de destruir a demanda endereçada aos outros. Diógenes quer mais, mais e mais 


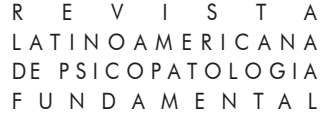

do seu tóxico, mas não demanda mais nada a ninguém. Contudo, como destacado por Assoun (2015), de forma subjacente a essa apetência voraz deve-se supor uma figura encriptada de uma demanda das mais virulentas em sua dimensão inconsciente.

\section{$O$ contexto de precariedade e marginalização social: dissidência tóxica e resistência}

A história de Diógenes e sua vinculação com o crack são intrinsecamente ligadas ao processo estrutural de produção e reprodução da desigualdade social, que constitui uma classe marginalizada e estigmatizada, destinada a viver em uma situação de precariedade e vulnerabilidade social, sujeita a diferentes formas de violências, desde as simbólicas àquelas que se dão no real do corpo. Proveniente de uma família que pertence a uma classe social destituída de capital econômico e cultural, marcada pela pobreza e vulnerabilidade social, Diógenes segue certo "roteiro-padrão" de seus membros: abandono escolar precoce, inserção precária no mercado de trabalho, enfraquecimento e precarização dos laços com a maioria das esferas e instituições sociais, estigmatização e marginalização e, pela via mais extrema, desenvolvimento de um modo de vida violento e autodestrutivo.

Não se trata aqui de buscar apreender o contexto de precariedade e desigualdade social no qual Diógenes está imerso para concebê-lo como o "protótipo absoluto do sujeito sem" (Douville, 2012). Como ressaltado por Douville (2012), não é suficiente colocar o sujeito em situação de precariedade e exclusão como uma vítima. Faz-se necessário compreender os modos de habitar o corpo, o espaço e a palavra ainda presentes e em funcionamento e pensar não apenas nas forças e instâncias que negam e rejeitam o sujeito expurgado, mas, também, compreender aquilo que o próprio sujeito nega, aquilo que ele recusa, aquilo ao qual ele objeta.

Se buscamos elucidar o progressivo processo estrutural de marginalização e subintegração no tecido social ao qual Diógenes foi submetido e suas incidências na subjetividade, cabe igualmente um questionamento sobre os modos pelos quais ele se faz afetar, como ele se posiciona subjetivamente e como esse posicionamento se relaciona com um lugar fixo que ele dá ao crack em sua economia pulsional. A vinculação extrema que Diógenes estabelece com o crack pode ser compreendida, então, como uma forma de recusa e resistência a uma "certa modalidade de vida e de morte que lhe é imposta" 


\section{ARTIGOS}

(Rosa \& Poli, 2009). Por meio da vinculação exclusiva com o crack e do desinvestimento de outras relações e objetos, Diógenes organiza uma "dissidência tóxica" (Assoun, 2015), para fazer apelo a essa recusa e reembolsar-se por conta própria. Essa dissidência tóxica acentuará ainda mais o processo de anomia, enfraquecimento e subintegração no tecido coletivo e social ao qual Diógenes já estava exposto. Mostra-se pertinente aqui a ideia desenvolvida por Assoun (2015) de que a intoxicação pode seguir uma lógica de "aplicação de um direito de indenização imaginário" diante de um Outro (neste caso, sobretudo social) prejudicial.

As possibilidades de inserção na vida laboral e produtiva emergem como dimensão fundamental. Freud (1930/2010a) ressalta que uma das estratégias de busca de felicidade e defesa contra o sofrimento é a sublimação por meio do trabalho, desde o intelectual ao mais ordinário e acessível, que tem um lugar significativo na economia libidinal, enquanto possibilidade de deslocamento de grande proporção de componentes libidinais, narcísicos, agressivos e mesmo eróticos, o que lhe confere um valor indispensável na afirmação e justificação da existência dos indivíduos na sociedade.

Diante de sua posição de classe marginalizada e do seu processo de escolarização interrompido precocemente, restavam a Diógenes, como possibilidades de inserção no mercado de trabalho, ocupações precárias e desqualificadas. Essas ocupações são diametralmente opostas à ideia de atividades profissionais à qual Freud se refere, que, principalmente quando livremente escolhidas, rendem uma satisfação particular ao possibilitarem um destino sublimatório às moções pulsionais e constituem importante fonte de reconhecimento social. Ao contrário, por meio desses trabalhos precarizados, o sujeito é reconhecido - ou desprezado - unicamente enquanto corpo físico, dispêndio de energia muscular, explorado e mal remunerado pelas classes média e alta (Souza, 2009).

Nesse sentido, podemos interpretar a dissidência tóxica à qual Diógenes se entrega como uma forma inconsciente de resistência e de recusa por mais desastrosa que ela possa se mostrar - a essa trajetória que lhe é reservada. Diógenes exprime de maneira radical o excesso de corpo e de sensações e a escassez do simbólico e da palavra que se manifestam na toxicomania. Mas, se ele encarna ao extremo a condenação que, segundo Souza (2009), recai sobre as classes marginalizadas - ser corpo, sem alma ou mente - ele não se deixa capturar passivamente nesse aproveitamento alheio do seu corpo, não reconhecido em sua dignidade de corpo simbólico. Ao contrário, é ele mesmo quem explora seu corpo, fazendo dele o lugar primordial de 
excitação, satisfação e desejo e prescindindo — ainda que ilusoriamente — do outro, da palavra, do social e da cultura.

A dissidência tóxica de Diógenes pode ser interpretada, então, como uma estratégia de subjetivação em um contexto em que domina um processo estrutural de dessubjetivação dos indivíduos em situação de precariedade ser corpo, músculo, organismo, sem mente, sem subjetividade. Estratégia de subjetivação que se organiza primordialmente em torno do corpo, mas que subverte a ideia de um corpo dócil a ser explorado por outros e constrói um corpo de prazer, mas também de dor e sofrimento.

\section{Conclusões: o corpo no uso de crack e nas situações de precariedade e exclusão}

Destaca-se, no caso de Diógenes, certa confluência entre o corpo que é colocado em cena pela operação de intoxicação pelo crack e o lugar que é conferido ao corpo no processo de desigualdade social e marginalização.

476 Consideramos importante reter e sublinhar que a particularidade do estatuto do corpo no caso de Diógenes, essa organização da subjetividade em torno do corpo e da exploração sensorial e o engendramento de um corpo desancorado da palavra e do simbólico não é consequência simples e direta de sua vinculação com o crack. De forma articulada aos efeitos da droga sobre o corpo e sobre as dinâmicas pulsionais, inscrevem-se também as incidências e efeitos sobre as formas de vivenciar e habitar o corpo das situações de marginalização e vulnerabilidade social, em que os sujeitos são lançados aos confins do laço social e não são socialmente reconhecidos em sua dignidade de corpo simbólico.

Em situações de precariedade e exclusão, o corpo torna-se o lugar privilegiado da expressão pulsional em pane de representações (Douville, 2012). A exclusão e o enfraquecimento da participação no laço social podem engendrar uma retração psíquica e um enrijecimento gradual das possibilidades de conflitualização, estabelecendo outras formas de enodamento entre corpo e palavra e uma nova relação do sujeito com sua economia somática. Além disso, a dessimbolização do corpo dos indivíduos radicalmente excluídos da troca e do pacto social pode produzir uma degradação progressiva do corpo, corpos catastróficos, definhados, cortados por feridas e automutilações, marcados pela destrutividade (Douville, 2012). Onde a palavra simbólica é destituída, há uma gramática que se escreve no próprio corpo (Lins, 2004). 


\section{ARTIGOS}

O caso clínico de Diógenes evidencia que tanto o recurso ao tóxico quanto o contexto de precariedade acionam um processo de engendramento de um corpo desancorado da linguagem, de um distanciamento entre corpo e palavra. Diante disso, clinicamente, impõe-se a urgência de reaproximar corpo e palavra, de favorecer o restabelecimento da coalizão entre corpo e linguagem, de reintroduzir um fio que conecte pensamento, corpo e ato. Na clínica da exclusão, da precariedade e da toxicomania, a posição clínica consiste em apostar na ideia de que o corpo possa se deixar atingir pelo discurso, consiste no engendramento de queixas e narrativas ali onde o corpo invadiu a totalidade do espaço da fala e na construção de um vínculo pacificado entre corpo e linguagem, uma sorte de reapropriação do íntimo pelo sujeito (Benhaïm, 2012).

\section{Nota de agradecimento:}

Agradecemos aos professores do PPG-PsiCC/PCL/IP/UnB, Profa. Dra. Maria Inês Gandolfo Conceição e Prof. Dr. Áderson da Costa Júnior, pela leitura das versões preliminares deste trabalho.

\section{Referências}

Assoun, P. L. (2015). Psychanalyse et Addiction. In É-P. Toubiana (Org.), Addictologie Clinique (pp. 27-122). Paris, France: PUF.

Bertoni, N., \& Bastos, F. I. (2014). Pesquisa Nacional sobre o uso de crack: quem são os usuários de crack elou similares do Brasil? Quantos são nas capitais brasileiras? Rio de Janeiro: Editora ICICT/FIOCRUZ.

Benhaïm, M. (2012). Vivre est plus difficile que survivre? In O. Douville (Org.), Clinique psychanalytique de l'exclusion (pp. 137-162). Paris, France: Dunod.

Bucher, R. (1992). Drogas e drogadição no Brasil. Porto Alegre, RS: Artes Médicas.

Cocteau, J. (1985). Ópio: Diário de uma desintoxicação. São Paulo, SP: Brasiliense.

Costa, J. F. (2005). O vestígio e a aura. Corpo e consumismo na moral do espetáculo. Rio de Janeiro, RJ: Garamond.

Douville, O. (2012). Clinique psychanalytique de l'exclusion. Paris, France: Dunod.

Freud, S. (2006). O Ego e o Id. In Edição Standard Brasileira das Obras Psicológicas Completas de Sigmund Freud (pp. 15-80). Rio de Janeiro: Imago. (Trabalho original publicado em 1923).

Freud, S. (2010a). O mal-estar na civilização. In Obras Completas de S. Freud (pp. 


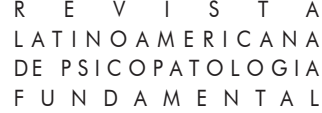

13-122). Trad. Paulo César de Souza. São Paulo, SP: Companhia das Letras. (Trabalho original publicado em 1930).

Freud, S. (2010b). Introdução ao narcisismo. In Obras Completas de S. Freud (pp. 13-50). Trad. Paulo César de Souza. São Paulo, SP: Companhia das Letras. (Trabalho original publicado em 1914).

Gurfinkel, D. (2011). Adicções: paixão e vício. Coleção Clínica Psicanalítica. São Paulo, SP: Casa do Psicólogo.

Lancetti, A. (2015). Contrafissura e plasticidade psíquica. São Paulo, SP: Hucitec.

Le Poulichet, S. (1987). Toxicomanías y psicoanalisis: Las narcosis del deseo. Buenos Aires, Argentina: Amorrortu.

Lins, D. (2004). Crueldade do devir e corpo drogado. Verve, 5, 186-207.

Nogueira Filho, D. M. (1999). Toxicomanias. São Paulo, SP: Escuta.

Rosa, M. D., \& Poli, M. C. (2009). Experiência e linguagem como estratégias de resistência: psicanálise e política. Psicologia \& Sociedade, 21 [Edição especial], $5-12$.

Rui, T. (2014). Nas tramas do crack: etnografia da abjeção. São Paulo, SP: Terceiro Nome

478 Santiago, J. (2001). A droga do toxicômano: uma parceria cínica na era da ciência. Rio de Janeiro, RJ: Jorge Zahar.

Sissa, G. (1999). O prazer e o mal: filosofia da droga. Rio de Janeiro, RJ: Civilização Brasileira.

Souza, J. (2009). A ralé brasileira: quem é e como vive. Belo Horizonte, MG: UFMG.

\section{Resumos}

(Diogenes and the "drug-making" body: the body's statute in crack abuse and social vulnerability situations)

This paper addresses the relationship between the forms of subjectivation that result from situations of social vulnerability and crack abuse. Drawing from a clinical case, examine we examined how crack's action in the pulsional body is connected to the subject's experience and to his or her social embeddedness in society and sociocultural reality. We observed a strong connection between the body's statute in the use of crack and the place assigned to the body in situations of social vulnerability and exclusion.

Key words: Crack; body; social vulnerability; psychoanalysis 


\section{ARTIGOS}

(Diogène et le corps comme «producteur des drogues»: le statut du corps dans consommation de crack et dans les situations de précarité et vulnérabilité sociale)

Cet article porte sur le rapport entre les modes de subjectivation résultants de situations de vulnérabilité sociale et la consommation du crack. À partir d'un cas clinique, on examine comment l'action du crack sur le corps pulsionnel se lie à l'expérience du sujet et à son rapport à l'autre, au lien social et à la réalité socioculturelle. On observe une étroite articulation entre le statut du corps engendré par la consommation du crack et la place accordée au corps dans les contextes de précarité et d'exclusion.

Mots clés: Crack, corps, vulnérabilité sociale, psychanalyse

(Diógenes y el cuerpo "productor de drogas": el estatuto del cuerpo en el uso abusivo de crack y en situaciones de precariedad y vulnerabilidad social)

Este artículo aborda la relación entre los modos de subjectivación que resultan de situaciones de vulnerabilidad social y abuso de crack. A partir de un caso clínico, se ha analizado de qué forma la acción del crack sobre el cuerpo pulsional se articula a la experiencia del sujeto y a su inscripción en el lazo social y en la realidad sociocultural. Se ha observado una estrecha articulación entre el cuerpo engendrado por el uso abusivo de crack y el lugar dado al cuerpo en situaciones de precariedad y exclusión.

Palabras clave: Crack, cuerpo, vulnerabilidad social, psicoanálisis

(Diogenes und der Körper als „Hersteller von Drogen“: der Status des Körpers in Bezug zum Crackkonsum und zu Situationen der Prekarität und sozialer Verwundbarkeit)

Dieser Artikel analysiert die Beziehung zwischen den verschiedenen Arten der Subjektivierung welche aus Situationen sozialer Verwundbarkeit und dem Konsum von Crack entstehen. Aufgrund einer klinischen Fallstudie untersuchten wir, auf welcher Weise die Wirkung des Cracks auf den Triebkörper sich auf die Erfahrung des Subjekts auswirkt, sowie auf seine Einfügung im sozialen Netz und in der sozio-kulturellen Realität. Eine enge Verbindung wurde festgestellt zwischen dem Status des Körpers der durch den Crackkonsum erzeugt wird und der zugeordneten Stelle des Körpers in Situationen der Prekarität und der Ausgrenzung.

Schlüsselwörter: Crack, Körper, soziale Verwundbarkeit, Psychoanalyse 


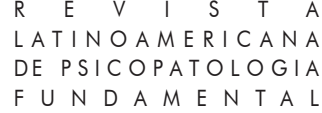

Citação/Citation: Richwin, I. F., \& Celes, L. A. M. (2017, setembro). Diógenes e o corpo "fabricador de drogas": o estatuto do corpo no uso abusivo de crack e nas situações de precariedade e vulnerabilidade social. Revista Latinoamericana de Psicopatologia Fundamental, 20(3), 465-480. http://dx.doi.org/10.1590/1415-4714.2017v20n3p465.4

Editores do artigo/Editors: Profa. Dra. Ana Maria Rudge e Profa. Dra. Sonia Leite.

Recebido/Received: 12.8.2016/ 8.12.2016 Aceito/Accepted: 5.10.2016 / 10.5.2016

Copyright: (C) 2009 Associação Universitária de Pesquisa em Psicopatologia Fundamental/ University Association for Research in Fundamental Psychopathology. Este é um artigo de livre acesso, que permite uso irrestrito, distribuição e reprodução em qualquer meio, desde que o autor e a fonte sejam citados / This is an open-access article, which permits unrestricted use, distribution, and reproduction in any medium, provided the original authors and sources are credited.

Financiamento/Funding: Os autores declaram não ter sido financiados ou apoiados. The authors have no support or funding funded to report.

Conflito de interesses/Conflict of interest: Os autores declaram que não há conflito de interesses / The authors have no conflict of interest to declare.

\section{IARA FLORRICHWIN}

Doutoranda do Programa de Pós-Graduação em Psicologia Clínica e Cultura da Universidade de Brasília - UnB (Brasília, DF, Br); Mestre em Psicologia Clínica e Cultura pela Universidade de Brasília.

SQS 306, Bloco D, apto 303.

70343-040 Brasília, DF, Br

iararaflor@gmail.com

\section{Luiz Augusto M. Celes}

Doutor em Psicologia Clínica pela Pontifícia Universidade Católica do Rio de Janeiro PUC-Rio (Rio de Janeiro, RJ, Br); Professor titular aposentado da Universidade de Brasília - UnB (Brasília, DF, Br); Pesquisador Colaborador no Programa de Pós-Graduação em Psicologia Clínica e Cultura, PCL/IP/UnB.

SQN 205, Bloco L, Apt. 303

70843-120 Brasília, DF

lamceles@gmail.com

This is an open-access article, which permits unrestricted use, distribution, and reproduction in any medium for non-commercial purposes provided the original authors and sources are credited. 